\title{
Towards High Power Density Metal Supported Solid Oxide Fuel Cell for Mobile Applications
}

\author{
Nielsen, Jimmi; Persson, Asa H.; Muhl, Thuy Thanh; Brodersen, Karen
}

Published in:

Journal of the Electrochemical Society

Link to article, DOI:

10.1149/2.0741802jes

Publication date:

2018

Document Version

Publisher's PDF, also known as Version of record

Link back to DTU Orbit

Citation (APA):

Nielsen, J., Persson, A. H., Muhl, T. T., \& Brodersen, K. (2018). Towards High Power Density Metal Supported Solid Oxide Fuel Cell for Mobile Applications. Journal of the Electrochemical Society, 165(2), F90-F96. https://doi.org/10.1149/2.0741802jes

\section{General rights}

Copyright and moral rights for the publications made accessible in the public portal are retained by the authors and/or other copyright owners and it is a condition of accessing publications that users recognise and abide by the legal requirements associated with these rights.

- Users may download and print one copy of any publication from the public portal for the purpose of private study or research.

- You may not further distribute the material or use it for any profit-making activity or commercial gain

- You may freely distribute the URL identifying the publication in the public portal 


\title{
Towards High Power Density Metal Supported Solid Oxide Fuel Cell for Mobile Applications
}

\author{
Jimmi Nielsen, ${ }^{z}$ Åsa H. Persson, Thuy Thanh Muhl, and Karen Brodersen \\ Department of Energy Conversion and Storage, Technical University of Denmark, 4000 Roskilde, Denmark
}

\begin{abstract}
For use of metal supported solid oxide fuel cell (MS-SOFC) in mobile applications it is important to reduce the thermal mass to enable fast startup, increase stack power density in terms of weight and volume and reduce costs. In the present study, we report on the effect of reducing the Technical University of Denmark (DTU) SoA MS-SOFCs support layer thickness from $313 \mu$ m gradually to 108 $\mu \mathrm{m}$. The support layer thickness decrease in the DTU co-sintering MS-SOFC fabrication route results in an increased densification of the support layer and a slight decrease in performance. To mitigate the performance loss, two different routes for increasing the porosity of the support layer and thus performance were explored. The first route is the introduction of gas channels by puncturing of the green tape casted support layer. The second route is modification of the co-sintering profile. In summary, the cell thickness and thus weight and volume was reduced and the cell power density at $0.7 \mathrm{~V}$ at $700^{\circ} \mathrm{C}$ was increased by $46 \%$ to $1.01 \mathrm{Wcm}^{-2}$ at a fuel utilization of $48 \%$. All modifications were performed on a stack technological relevant cell size of $12 \mathrm{~cm} \times 12 \mathrm{~cm}$.

(C) The Author(s) 2018. Published by ECS. This is an open access article distributed under the terms of the Creative Commons Attribution 4.0 License (CC BY, http://creativecommons.org/licenses/by/4.0/), which permits unrestricted reuse of the work in any medium, provided the original work is properly cited. [DOI: 10.1149/2.0741802jes]

(c)) BY
\end{abstract}

Manuscript submitted November 29, 2017; revised manuscript received January 3, 2018. Published January 30, 2018.

Solid oxide fuel cell (SOFC) is attractive due to the excellent power generation efficiency and fuel flexibility. The conventional ceramic electrolyte and anode supported SOFC (AS-SOFC) is limited to stationary power generation applications as a result of the difficulty of quick startup and the high operating temperatures of 700 to $1000^{\circ} \mathrm{C}$. If quick startup of a SOFC is realized, mobile applications may be considered. To enable this, it is important to shorten the startup time and reduce the heat cycle performance degradation and increase stack power density both in terms of weight and volume. As an approach to solving these problems, metal supported SOFCs (MS-SOFCs) have attracted attention. The development of this new generation of SOFC is currently in progress. DTU Energy's MS-SOFC technology is based on co-sintering of laminated tape casted electrolyte, anode and support layers in a reducing atmosphere. This implies that the sintering shrinkage of the different layers must be matched sufficiently so that the mechanical stresses originating from any mismatch in sintering shrinkage of the individual layers can be absorbed by the cell structure. If the cell structure is unable to absorb the mechanical stresses, the cell will crack. Perfect matching of sintering shrinkage of the layers is practically very difficult as e.g. the electrolyte layer needs to be completely dense and thus gastight, while the anode and support layers in contrast needs to be highly porous to allow sufficient gas transport.

An overview and recent progress of MS-SOFCs have been reviewed in Ref. 1. The company Ceres Power founded in 2001 is at present the organization, which most effectively has demonstrated up scaled large cell sized $>80 \mathrm{~cm}^{2}$ MS-SOFC stack technology. This is followed by consortia involving the company Plansee. At last MSSOFC stacking has been demonstrated within consortia consisting of Topsoe fuel cell (TOFC no longer in operation), DTU and others. Apart from the mentioned players other MS-SOFC R\&D activities are predominantly performed on button cell level by various university groups..$^{2-11}$ The present MS-SOFC designs are to our knowledge not optimized for mobile applications in terms of rapid startup and volumetric and gravimetric power densities. For example, the Plansee design consist of very thick substrates of $1 \mathrm{~mm},{ }^{12,13}$ whereas exact specification of the Ceres Power cell and stack design is shrouded in some uncertainty. However, from early publication within Ceres Power's relatively long history it is possible to get a substrate thickness of $300 \mu \mathrm{m}$ from a modelling study in $2005 .{ }^{14}$ The performance of the different MS-SOFC designs are for various reasons difficult to compare for among other reasons very different aimed operation temperatures e.g. Plansee $800^{\circ} \mathrm{C}$ and DTU $650-700^{\circ} \mathrm{C}$. Ceres Power is aimed at an even lower temperature of $500-600^{\circ} \mathrm{C}$ due to the use

zE-mail: jini@dtu.dk of a doped ceria based electrolyte layer. Doped ceria based electrolyte is a mixed ionic and electronic conductor (MIEC). The MIEC behavior increases with increasing temperature and results in a partial short circuit. This is observed as a lowered open circuit voltage (OCV) compared to the theoretical value. It furthermore complicates performance evaluation and comparison as the degree of electronic conduction of the doped ceria electrolyte is polarization dependent. Nonetheless, to overcome the issues of electrolyte MIEC behavior, Ceres Power has recently introduced a so-called electronic blocking layer. ${ }^{15}$ The result in a 3 layered electrolyte configuration. How such further complications to the cell design affects the overall stack cost is unclear.

It is the aim of the present study to explore the feasibility of reducing the metal support (MS) layer thickness and for improved performance explore the feasibility of opening up the support layer. For opening up the support layer two routes are explored. The first route is introduction of gas channels via puncturing of the green tape casted support layer. The second route is modification of the sintering profile. Realizing this may serve as a means of enabling faster startup and increase the stack power density in terms of weight and volume.

\section{Experimental}

Cell fabrication.-The half-cell (i.e. metal support, anode, electrolyte) processing and infiltration route, described in Ref. 16,17, was also used in this study. The processes involved tape casting of the layers: metal-support (a ferritic stainless $\mathrm{Fe} 22 \mathrm{Cr}$ steel alloy), cermet backbone (with $0-50$ vol.\% Y-doped doped $\mathrm{ZrO}_{2}$ with respect to metal), and ScYSZ electrolyte, followed by a subsequent co-sintering of these layers in a reducing atmosphere $\left(\mathrm{H}_{2} / \mathrm{Ar}\right)$. The electrocatalytically active phase, comprising a precursor solution of $\mathrm{Ce}_{0.8} \mathrm{Gd}_{0.2} \mathrm{O}_{1.9}$ and $\mathrm{Ni}$ (hereafter referred to as $\mathrm{Ni}: \mathrm{CGO}$ ), was infiltrated as a next step. The infiltration of electrocatalysts followed the same procedure as described elsewhere. ${ }^{18}$ Cells being evaluated for electrochemical performance were deposited with a $\mathrm{Ce}_{0.9} \mathrm{Gd}_{0.1} \mathrm{O}_{1.95}$ inter-diffusion barrier layer on the electrolyte, using the physical vapor deposition technique as described in Ref. 16. Finally, a thin $(\sim 15 \mu \mathrm{m})$ cathode layer comprising of $\left(\mathrm{La}_{0.6} \mathrm{Sr}_{0.4}\right)_{0.99} \mathrm{CoO}_{3-\delta}$ (LSC) was applied by screen printing as the last component. For introduction of gas channels into the MSSOFC support layer, the green tape casted support layer was rolled to various degrees with a spiked roller. The increasing porosity of the support layer was achieved by a 5 fold reduction of the dwell time at the sintering temperature $\mathrm{T}_{\max }$.

Electrochemical characterization.-The single cells were cut out of large $12 \mathrm{~cm} \times 12 \mathrm{~cm}$ cells and had a $54 \mathrm{~mm} \times 54 \mathrm{~mm}$ cell area with 


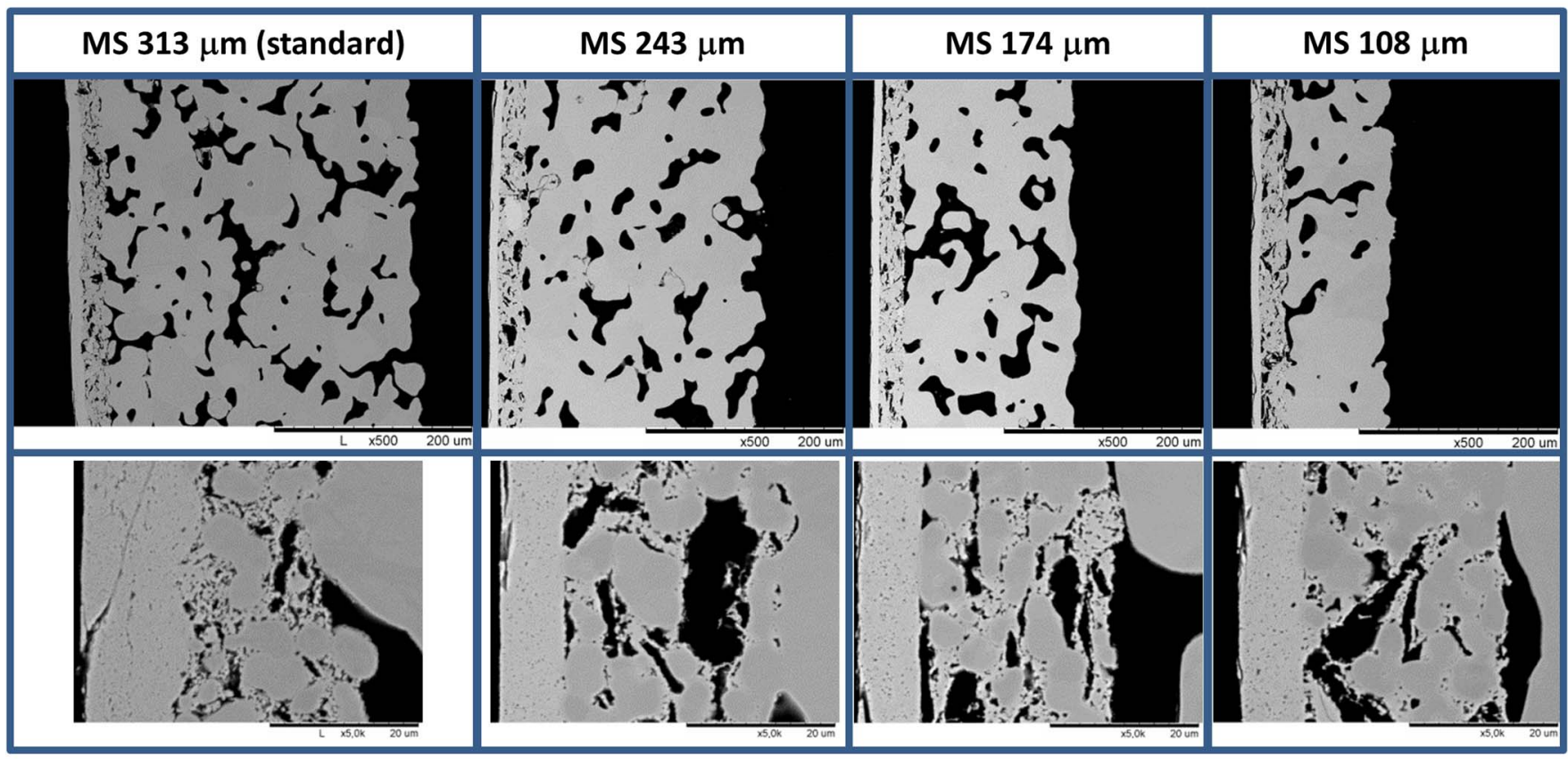

Increasing metal support densification and poorer cell performance

Figure 1. Fabricated $12 \mathrm{~cm} \times 12 \mathrm{~cm}$ half-cell with systematic variation of the metal support (MS) layer thickness. DTU state-of-the-art (SoA) MS-SOFC support layer thickness is $\sim 313 \mu \mathrm{m}$.

an active area of $16 \mathrm{~cm}^{2}$ (defined by the screen-printed cathode layer). The cells were tested in an alumina housing used for conventional anode-supported cells, and the test house and positions of voltage probes and current pick-up points were as described in Ref. 19. A flat $\mathrm{Ni}$ net was used as a current collector on the anode side, and Au net was used on the cathode side. The cell rested directly on the flat Ni net with the edges being sealed with glass. The fuel gas was distributed from one side to the other via milled gas trenches in a $1 \mathrm{~mm}$ thick $\mathrm{Ni}$ block, which was embedded in the alumina test housing. On top of this arrangement, on the cathode side, an alumina block with the flat current collecting Au nets was put and a weight of $4 \mathrm{~kg}$ was applied. No sealing was used on the cathode side since the gas was distributed from the middle of the cathode and outwards via milled gas trenches in the alumina top block. The cells were heated to $800^{\circ} \mathrm{C}$ for $5 \mathrm{~h}$ in order to seal the cells and sinter the cathode before the performance and durability tests were started. During startup air was supplied to the cathode and dry $9 \% \mathrm{H}_{2}$ in $\mathrm{N}_{2}$ to the anode side (to prevent corrosion of the metal support at the elevated temperature).

Polarization curves and impedance data were collected in the temperature range $650-750^{\circ} \mathrm{C}$ with $4 \%$ and $20 \%$ humidified $\mathrm{H}_{2}$ on the anode side, and air or oxygen on the cathode side. The fuel and air flows were maximum 1.5 and $8.75 \mathrm{Nl} \mathrm{h}^{-1} \mathrm{~cm}^{-2}$, respectively. Specified fuel utilization (FU) corrected Area Specific Resistance (ASR corr $_{\text {) }}$ ) within the present paper was calculated as outlined in Ref. 19.

The electrochemical impedance (EIS) data was recorded using a Solartron 1260 Gain-Phase Analyser and a Solartron 1255B frequency response analyser (Solartron Instruments, Houston, Texas) with a perturbation amplitude of $60 \mathrm{~mA}$. The impedance was recorded in the frequency range $96.850 \mathrm{kHz}-0.096850 \mathrm{~Hz}$ with 12 points per decade. For visualization at which frequencies changes occur in the impedance spectra during testing, the method "Analysis of Difference in Impedance Spectra" (ADIS) was used ${ }^{20}$ along with the method "Distribution of Relaxation Times" (DRT). ${ }^{21}$ In the ADIS method the difference between the derivative of the real part of the impedance with respect to frequency is plotted as a function of $\log$ (frequency).

Microstructural characterization.-The microstructure of the various cell samples was investigated using polished cross-sections. The polished cross-sections were prepared by vacuum embedding the samples in Struers epoxy resin (Epofix); ground using SiC paper; polished using 6, 3 and $1 \mu \mathrm{m}$ diamond paste, and then carbon coated to eliminate surface charging. Scanning electrotron microscopy (SEM) imaging with backscattered electrons was performed using a Hitachi TM1000 tabletop SEM.

\section{Results and Discussion}

Effect of reducing the metal support thickness.-The effect of reducing the half-cell metal support layer thickness is shown in Figure 1. As can be seen, the effect of reducing the support layer thickness from the standard DTU state-of-the-art (SoA) MS-SOFC thickness of $\sim 313 \mu \mathrm{m}$ gradually to $108 \mu \mathrm{m}$ is predominantly an increase in support layer densification. The cause for the densification is the sintering mismatch between the layers. The ScYSZ layer sintering starts at a lower temperature than the sintering of the anode and support layer. Thus, at reduced support layer thicknesses the electrolyte layer has a more dominating role in the overall shrinkage of the co-sintered multilayered half-cell structure. A lower support layer thickness in itself will lower the anode gas diffusion length. However, the increase in support layer densification results in a reduced porosity $\varepsilon$, reduced 


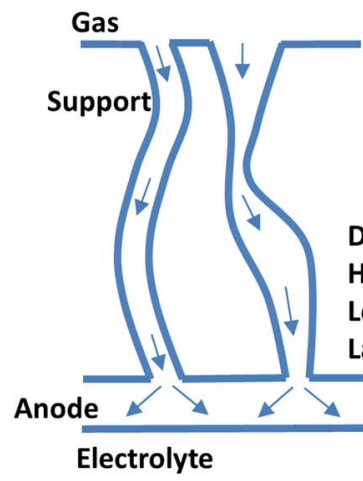

Increasing densification

Decrease in porosity

Higher tortuosity

Lower density of gas pathways

Lateral gas diffusion in anode layer

Electrolyte

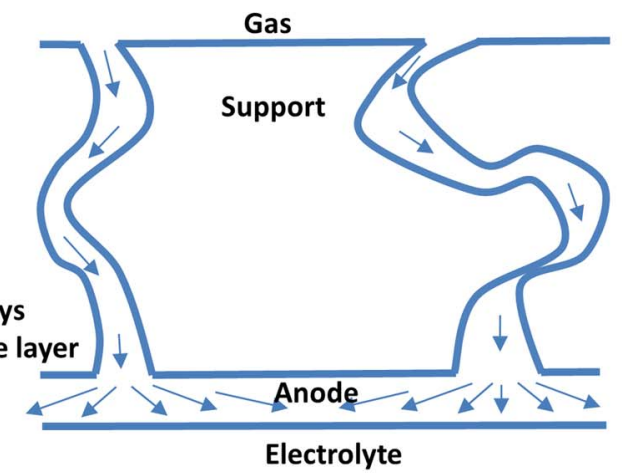

Figure 2. Sketch of envisioned consequences of increased support layer densification.

density of percolated gas transport pathways through the support layer and furthermore it increases the tortuosity $\tau$ of the gas transport pathways. That it is reasonable to expect higher tortuosity values with increasing support layer densification has previously been illustrated by studies of a DTU MS-SOFC with a relatively dense support layer. ${ }^{22}$ In here high tortuosity values around 5 were found from modelling of 3D microstructural reconstructions. For comparison, AS-SOFCs with the conventional Ni:YSZ cermet anode have typically a tortuosity value of around or slightly below $2 .{ }^{23-25}$ It must be noted that some confusion regarding tortuosity $\tau$ and tortuosity factor $\tau^{2}$ exist within literature as pointed out by Epstein. ${ }^{26}$ The impact of porosity and tortuosity on the effective diffusion through a porous structure is conveniently illustrated by the following relationship: ${ }^{26}$

$$
D_{e f f}=D \cdot \frac{\varepsilon}{\tau^{2}}
$$

Here $\mathrm{D}_{\text {eff }}$ is the effective diffusion coefficient, while $\mathrm{D}$ is the bulk diffusion coefficient. Thus, the gas permeability but also the uniformity of the flowfield through the support layer is reduced. The latter may result in a larger degree of lateral gas transport within the anode layer. The envisioned consequences of an increased support densification is summarized in Figure 2.

Besides having an effect on the gas transport properties, a reduced support porosity and channel connectivity will also have an effect on the electrocatalyst loading and distribution when deposited by infiltration. A higher porosity will accumulate a larger amount of liquid and thus electrocatalyst upon an infiltration cycle. For these reasons it is expected that higher loadings and thus thicker electrocatalyst coatings will be the result for highly porous microstructures with large pores. Furthermore, in the case of dense microstructures it may be difficult to deposit sufficient anode electrocatalyst by infiltration without blocking or severely reducing the gas transport properties of the support layer. For a broad pore size distribution, there seems to be a tendency that there is an accumulation of electrocatalyst associated with the smaller pores. Thus, the electrocatalyst is not evenly distributed within the microstructure. A possible explanation could be that the capillary forces has a more predominant effect for the smaller pores. Therefore upon water evaporation when the sample is heated after infiltration, the water within the smallest pores is the last to evaporate. Since the concentration increases as water is evaporated a larger electrocatalyst deposition will take place in association with the smallest pores. For a more even electrocatalyst deposition it therefore seems desirable with a narrow pore size distribution. However, for other purposes such as a given desirable sintering characteristics this may not be feasible. It should be noted that the effect of infiltration procedures and microstructure on electroctatalyst distribution has been considered before for example in Ref. 27.

Increased support porosity by creation of gas channels.-In Figure $3 \mathrm{~A}$ a gas channel is seen from the top, which has been prepared by puncturing of the green tape casted support layer. A cross
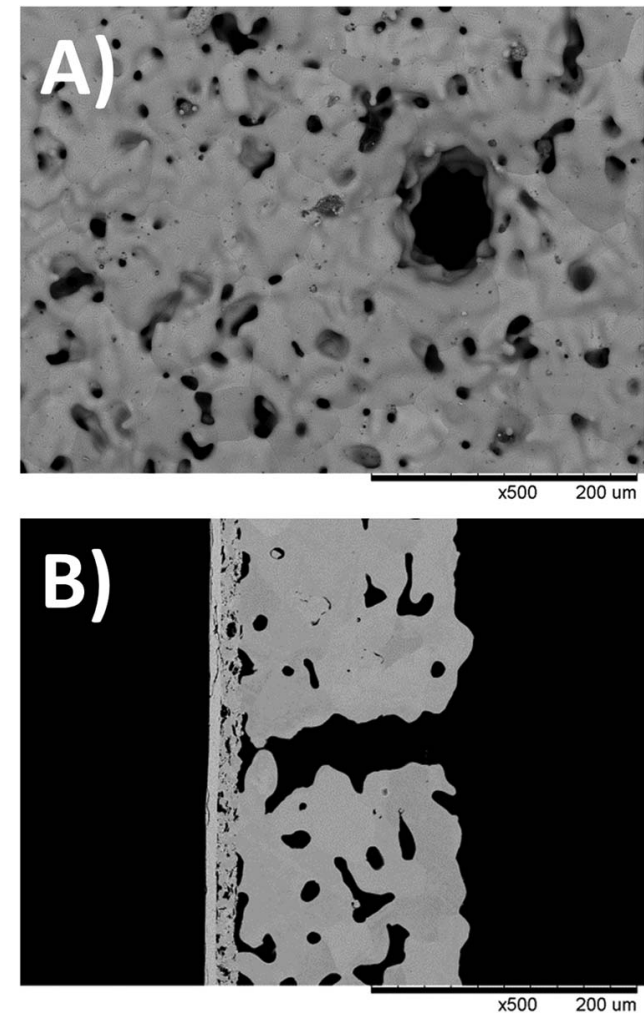

Figure 3. A) Top view SEM image of the introduced gas channel of an uninfiltrated half cell. B) Cross section SEM image of the introduced gas channel of an uninfiltrated half-cell.

section of such a gas channel is shown in Figure 3B. From the images it can be seen that the diameter of the introduced gas channels are approximately $40 \mu \mathrm{m}$. Cells A and B with two different density of gas channels were fabricated. A rough estimation of the gas channel density and average distance between gas channels is summarized in Table I. In order for the gas transport via gas channels to sense each other and thereby have an effect on the anode area, it seems as a first approximation reasonable to assume that the spacing between

Table I. Gas channel density of studied cells.

\begin{tabular}{ccc} 
Cell & $\begin{array}{c}\text { Density of gas } \\
\text { channels per } \mathrm{mm}^{2}\end{array}$ & $\begin{array}{c}\text { Average distance between } \\
\text { gas channels } / \mu \mathrm{m}\end{array}$ \\
\hline A & 2 & 710 \\
B & 18 & 235
\end{tabular}


A)

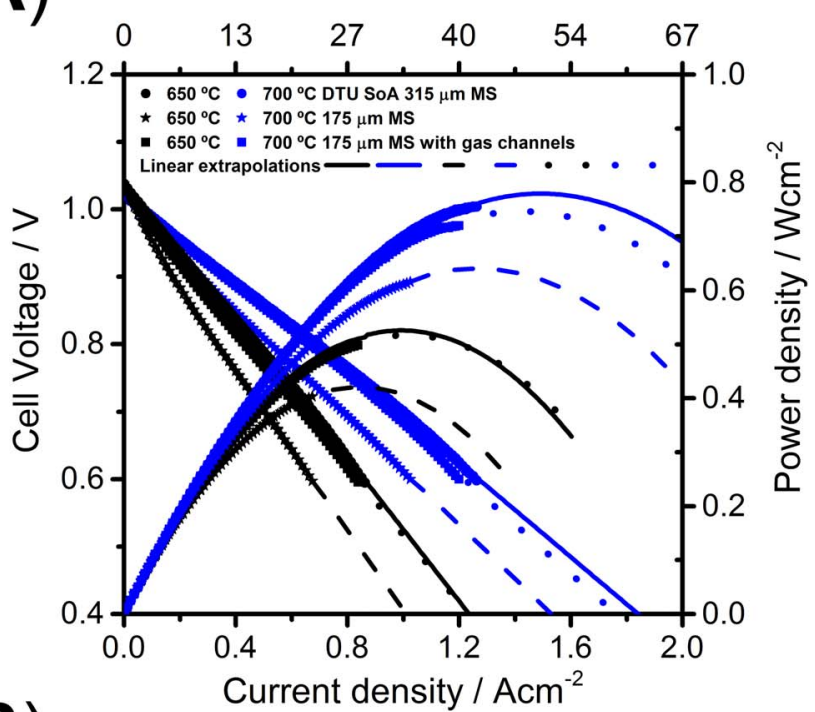

B)

Current density / $\mathrm{Acm}^{-2}$

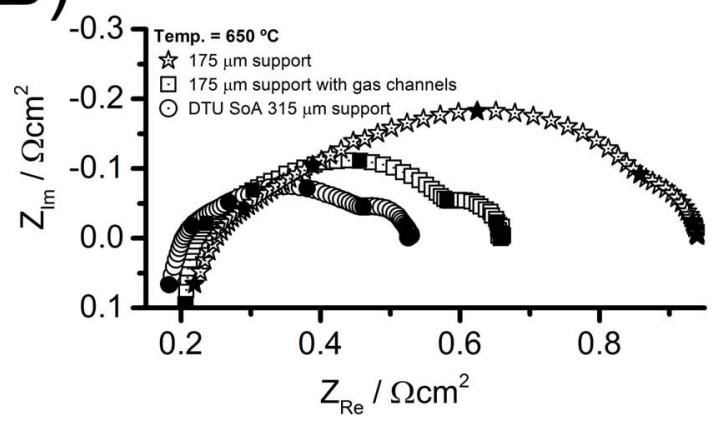

Figure 4. Electrochemical characteristics at $650^{\circ} \mathrm{C}$ and $700^{\circ} \mathrm{C}$ with air as oxidant and $20 \%$ humidified $\mathrm{H}_{2}$ as fuel. A) IV characteristics at $650^{\circ} \mathrm{C}$ and $700^{\circ} \mathrm{C}$. The fuel utilization corrected area specific resistance ( $\mathrm{ASR}_{\text {corr }}$ ) of the cells at $650^{\circ} \mathrm{C}$ are as follows $\mathrm{ASR}_{\text {corr }}$ (DTU SoA $313 \mu \mathrm{m} \mathrm{MS}$ ) $=0.453 \Omega \mathrm{cm}^{2}$, $\operatorname{ASR}_{\text {corr }}(175 \mu \mathrm{m} \mathrm{MS})=0.626 \Omega \mathrm{cm}^{2}, \operatorname{ASR}_{\text {corr }}(175 \mu \mathrm{m}$ MS with gas channels $)$ $=0.492 \Omega \mathrm{cm}^{2}$. B) The associated impedance characteristics at open circuit voltage at $650^{\circ} \mathrm{C}$. The solid points indicate the frequencies $96.85 \mathrm{kHz}, 9.685$ kHz, $968.5 \mathrm{~Hz}, 96.85 \mathrm{~Hz}, 9.685 \mathrm{~Hz}, 968.5 \mathrm{mHz}, 96.85 \mathrm{mHz}$.

the gas channels should be comparable to that of the thickness of the support layer. This is the case for B cells with the highest density of gas channels where the average distance between the gas channels is approximately $235 \mu \mathrm{m}$, which is close to the support layer thickness of $175 \mu \mathrm{m}$. In Figure 4 the electrochemical test results are shown of a DTU SoA MS-SOFC with $313 \mu \mathrm{m}$ thick support together with cells with a support thickness of $175 \mu \mathrm{m}$ with and without introduced gas channels at $650^{\circ} \mathrm{C}$ and $700^{\circ} \mathrm{C}$ respectively. As can be seen, the lowering of the support layer thickness from $313 \mu \mathrm{m}$ to $175 \mu \mathrm{m}$ results in a performance loss with an increase in $\mathrm{ASR}_{\text {corr }}\left(650^{\circ} \mathrm{C}\right)$ from $0.453 \Omega \mathrm{cm}^{2}$ to $0.626 \Omega \mathrm{cm}^{2}$. The introduction of gas channels in the cell with $175 \mu \mathrm{m}$ thick support with a low density of gas channels

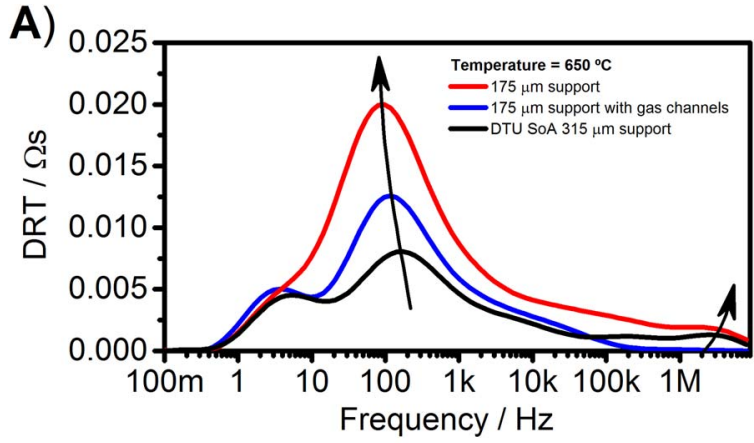

B)

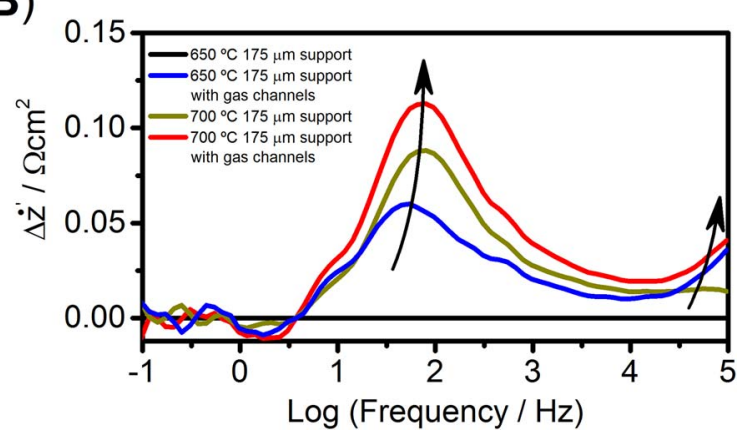

Figure 5. Distribution of Relaxation Times (DRT) and Analysis of Differnece in Impedance Spectra (ADIS) plots of the impedance data in Figure 4B. For the ADIS plots the impedance spectrum of the cell with $175 \mu \mathrm{m}$ support layer has been used as reference.

2 per $\mathrm{mm}^{2}$ according to Table I did not result in any performance improvement. However, the high density of gas channels 18 per $\mathrm{mm}^{2}$ according to Table I did result in a performance improvement with an $\mathrm{ASR}_{\text {corr }}\left(650^{\circ} \mathrm{C}\right)$ of $0.492 \Omega \mathrm{cm}^{2}$. This is to be considered similar to the performance of SoA cells. The associated impedance characterization at $650^{\circ} \mathrm{C}$ at open cicuit voltage conditions are shown in Figure 4B. In Figure 5 the impedance spectra and differences between the spectra is visualized in terms of distribution of relaxation times (DRT) and analysis of difference in impedance spectra (ADIS). For the ADIS plots in Figure 5B, the impedance spectrum of the worst performing cell with MS $175 \mu \mathrm{m}$ at $650^{\circ} \mathrm{C}$ was used as reference. Since the differences between the MS-SOFCs lies in the anode architecture only the anode processes are affected. From previous anode development studies ${ }^{18}$ and detailed impedance studies ${ }^{28}$ the following processes summarized in Table II have been identified. From the two ways of visualizing the processes and changes hereof in Figure 5 consensus seems exist that it is predominantly differences in the two processes located at $\sim 100 \mathrm{~Hz}$ and at $>50 \mathrm{kHz}$, which is observed among the cells. The process at $100 \mathrm{~Hz}$ is the coupling between oxide ionic conduction of the infiltrated Ni:CGO electrocatalyst coating and the faradaic oxidation reaction at the surface of the coating. The coupling is appropriately described by a so-called transmission line. For further details and justification the reader is referred to Refs. 28-30. The high frequency process at around $50 \mathrm{kHz}$ is the oxide ion charge transfer at the interface between the anode and the electrolyte layer.

Table II. Summary of impedance spectroscopy identified anode related processes. ${ }^{28}$ The given impedance arc summit frequencies are for a temperature of $650^{\circ} \mathrm{C}$.

Impedance resolved processes in MS-SOFC Ni:CGO impregnated anode

\begin{tabular}{lccc}
\hline Freq. & $\sim 500 \mathrm{kHz}$ & $\sim 100 \mathrm{~Hz}$ & $\sim 30 \mathrm{~Hz}$ \\
\hline Process & $\begin{array}{c}\text { Possible charge transfer of } \mathrm{O}^{2-} \text { at } \\
\text { anode/electrolyte interface }\end{array}$ & $\begin{array}{c}\text { Electrochemical response of mixed } \\
\text { ionic and electronic conducting } \\
\text { composite anode }\end{array}$ & Gas diffusion
\end{tabular}


A)
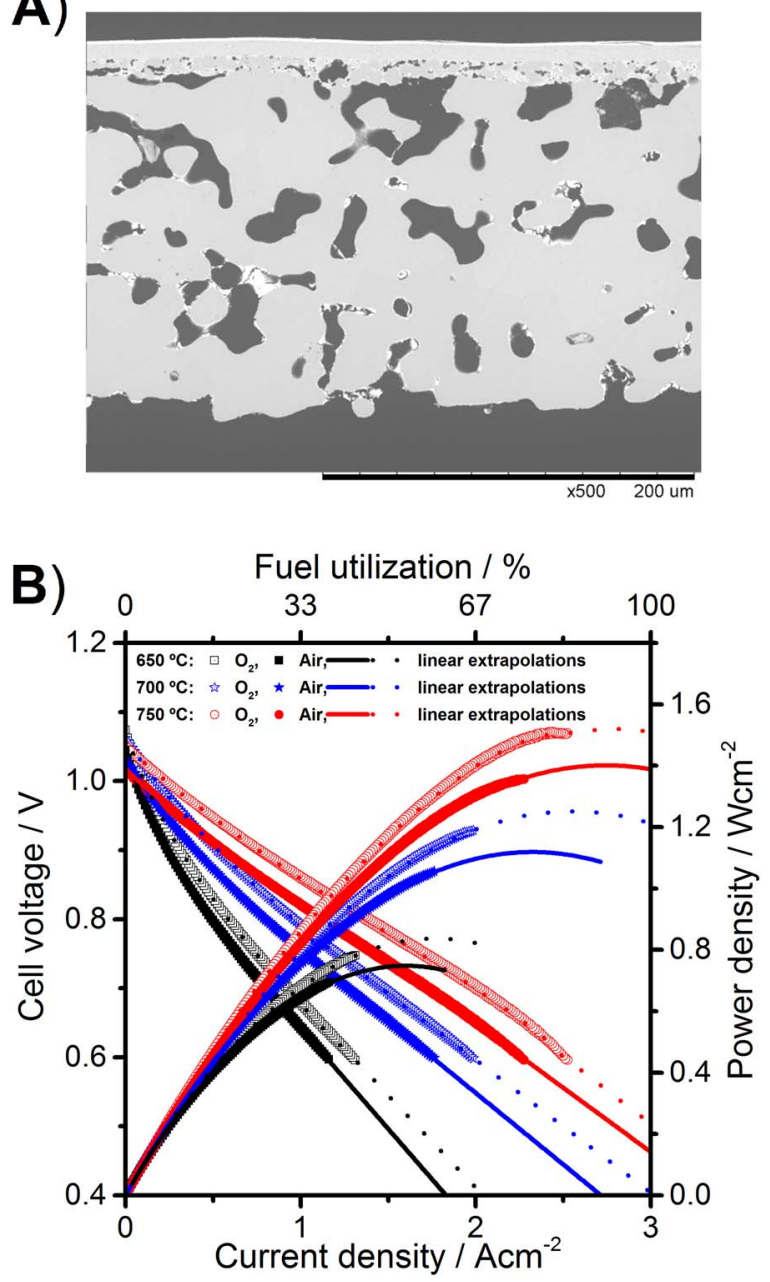

Figure 6. A) Cross section image of MS-SOFC with support layer thickness of $175 \mu \mathrm{m}$ with a more open microstructure than DTU SoA in Figure 1. B) Electrochemical characteristics of MS-SOFC in A) with air and oxygen as oxidant and $20 \%$ humidified $\mathrm{H}_{2}$ as fuel.

The process is presumably somewhat overlapped with the response of the electrolyte grain boundaries. The two processes affected are both dependent on the Ni:CGO electrocatalyst coating thickness. A thicker electrocatalyst coating will improve the oxide ion conduction of the anode and thus the anode transmission line response at $\sim 100 \mathrm{~Hz}$. Furthermore, a thicker coating will make it more favorable for the oxide ion charge transfer processs at the anode/electrolyte interface to spread out and utilize a larger area. This leads to a lowering of the resistance. However, despite that the anode functional layer fabrication procedure is unchanged, it cannot be ruled out that the anode microstructure is affected by the changes in the support layer during co-sintering. A denser anode microstructure is expected to have a similar effect as a thinner electrocatalyst coating as discussed previously. The porous structure of the anode can as in porous electrode theory be modelled as an array of columns each representing a transition line. ${ }^{28-30} \mathrm{~A}$ denser anode microstructure would in this interpretation correspond to a lower density of columns/transmission lines per area. Thus, it is a simple active anode/electrolyte area affect, where both the processes at $100 \mathrm{~Hz}$ and $>50 \mathrm{kHz}$ are affected.

For comparison of performances we will from here on use $0.7 \mathrm{~V}$ at $700^{\circ} \mathrm{C}$ as bench marking condition for the performance of MSSOFCs. In Figure 4 it is possible to see that the performance at bench marking conditions of DTU SoA MS-SOFC is $0.69 \mathrm{Wcm}^{-2}$ at a FU of $33 \%$.
A)
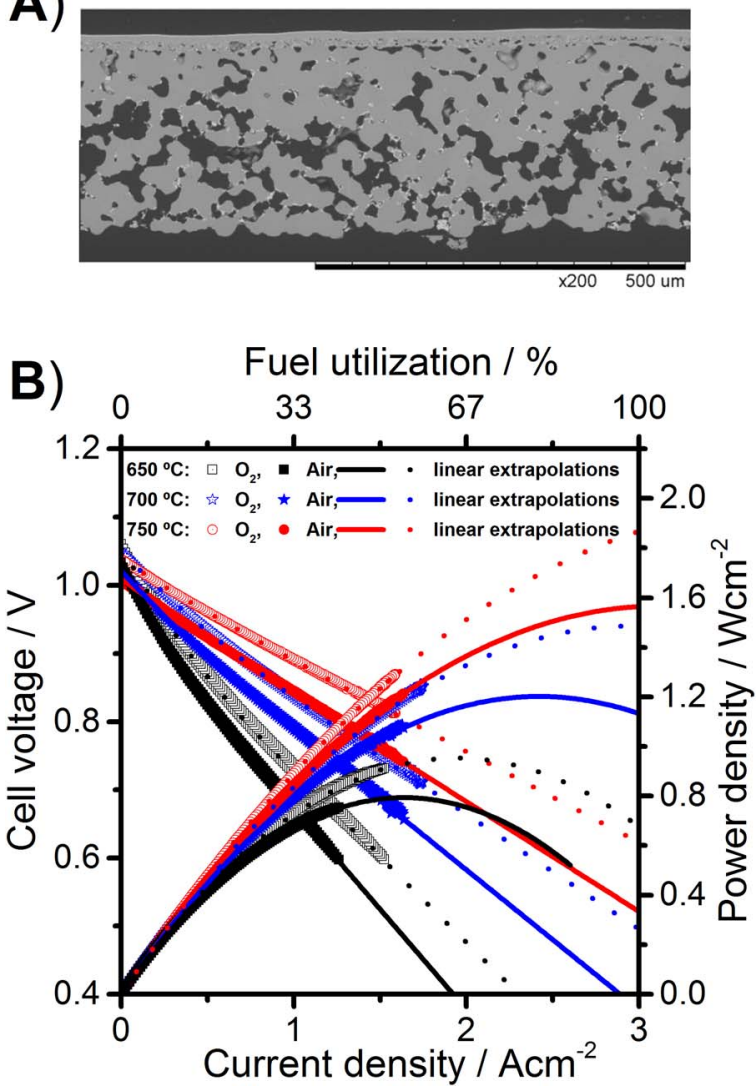

Figure 7. A) Cross section image of MS-SOFC with support layer thickness of $240 \mu \mathrm{m}$ with a significantly more open microstructure than DTU SoA in Figure 1. B) Electrochemical characteristics of MS-SOFC in A) with air and oxygen as oxidant and $20 \%$ humidified $\mathrm{H}_{2}$ as fuel.

Increased support porosity via 5 fold reduction in the dwell time of the maximum sintering temperature.-In Figure 6A a cross section of a MS-SOFC half cell with a $\sim 175 \mu \mathrm{m}$ thick support is seen, where the porosity of the support layer has successfully been increased in comparison to the DTU SoA MS-SOFCs in Figure 1. The associated performance is shown in Figure 6B, where it is possible to see an improved performance of $0.89 \mathrm{Wcm}^{-2}$ at bench marking conditions @ $700^{\circ} \mathrm{C}, 0.7 \mathrm{~V}$ with a $\mathrm{FU}$ of $43 \%$. In addition, the performance characteristics can be seen of using pure oxygen as oxidant, which results in significant performance improvements. This illustrates that there also is a clear scope for further improvement of the cathode in future cell performance development. For historical reasons and as a standard polarization curves are stopped at $0.6 \mathrm{~V}$ at DTU. However, there are no indications or guideline within the literature that SOFCs cannot be operated at lower potentials and thereby higher power densities. Nevertheless, it is commonly accepted that degradation rates are usually dependent on the degree of polarization/current load, temperature and used fuel utilization. To illustrate the potential of the studied MS-SOFCs the polarization curves are linearily extrapolated, which furthermore provide potential peak power densities (PPD). In Figure 7A a cross section of a MS-SOFC half cell with a $\sim 240 \mu \mathrm{m}$ thick support can be seen, with the most open support microstructure (highest porosity) of the studied MS-SOFCs. From Figure 7B the associated performance characteristics can be seen, which shows a significantly improved performance of $1.01 \mathrm{Wcm}^{-2}$ at bench marking conditions @ $700^{\circ} \mathrm{C}, 0.7 \mathrm{~V}$ with a FU of $48 \%$. The peak power densities at $700^{\circ} \mathrm{C}$ of DTU SoA MS-SOFC in Figure 4 and the improved cells in Figures 6 and 7 are $0.78 \mathrm{Wcm}^{-2}(0.52 \mathrm{~V} \& \mathrm{FU} 50 \%), 1.12 \mathrm{Wcm}^{-2}(0.48 \mathrm{~V}$ $\& \mathrm{FU} 78 \%)$ and $1.20 \mathrm{Wcm}^{-2}(0.50 \mathrm{~V} \& \mathrm{FU} 81 \%)$ respectively. This corresponds to a performance increase of $54 \%$ and even more if the 
effect of FU is taken into consideration. The latter will be discussed further in the following section overall discussion. For the peak power densities at $750^{\circ} \mathrm{C}$ in Figures 6 and 7 the fuel utilization is $92 \%$ and $100 \%$, which clearly is unrealistic in the sense that the linear extrapolation is invalid. The gas conversion resistance (change in Nernst potential) will approximately for fuel utilization lower than $10 \%$ and higher than $90 \%$ be highly nonlinear and increase drastically. ${ }^{31-33}$ The consequence is that in particular the peak power density at $750^{\circ} \mathrm{C}$ in Figure 7 will be somewhat lower than the $1.56 \mathrm{Wcm}^{-2}$, which the linear extrapolated curve indicate.

\section{Overall Discussion}

It was demonstrated, that it was feasible to decrease the support layer thickness substantially. From a processing perspective MSSOFCs with a $108 \mu \mathrm{m}$ thick support is handling wise somewhat challenging, whereas MS-SOFC with a support thickness of at least $150 \mu \mathrm{m}$ seems okay. However, an increasing densification of the support layer was observed as the thickness was lowered. To avoid this, a better sintering shrinkage match of the individual co-sintered layers need to be achieved or alternative routes for opening up of the support layer needs to be explored. In this study, it was demonstrated that it is possible to introduce gas channels in the MS-SOFCs via puncturing of the green support layer tape. From the results, it is clear that a certain density of gas channels is needed before it is possible to get an effect on the cell performance. Even with a relatively high density of gas channels with a mutual average spacing of 235 $\mu \mathrm{m}$, gastight electrolyte layers on a large cell size of $12 \mathrm{~cm} \times 12$ $\mathrm{cm}$ were achieved. However, it is expected that when continuously increasing the gas channel density by puncturing of the green support layer tape, the sintering characteristics will be affected at some point. This change in sintering characteristics might ultimately affect the co-sintering process and thus the quality of the electrolyte layer. A further implication of the introduced gas channels is that it represents a significant broadening of the pore size distribution. This is expected to have some impact on the distribution of Ni:CGO electrocatalyst deposition via infiltration. For instance it seems reasonable to expect a somewhat higher electrocatalyst loading at or near the large pores (e.g. gas channels). The impedance and the change hereof in Figures $4 \mathrm{~B}$ and 5 were found to be dependent on the support layer densification. This can be understood in terms of the deposited electrocatalyst coating thickness as a function support layer densification. However, a denser support microstructure is also expected to affect and limit gas transport properties as illustrated in Figure 2. The tested condition with $20 \%$ humidified $\mathrm{H}_{2}$ as fuel minimizes both the gas diffusion and gas conversion resistances and are at this condition relatively insensitive to small variations. ${ }^{31-33}$ This is unlike the situations of gas mixtures with either low $\mathrm{H}_{2}$ or $\mathrm{H}_{2} \mathrm{O}$. This may explain why these processes seem relatively unaffected upon the microstructural changes. However, if we for simplicity consider the $\mathrm{H}_{2}$ gas flux $\mathrm{J}\left(\mathrm{H}_{2}\right)$ to be governed by diffusion (Ficks first law):

$$
J\left(H_{2}\right)=-D_{e f f} \frac{\partial C_{H_{2}}}{\partial x}
$$

The driving force for the flux $\mathrm{J}\left(\mathrm{H}_{2}\right)$ will be the concentration gradient through the anode and support layers, which still is high with $20 \%$ humidified $\mathrm{H}_{2}$ as fuel at OCV conditions. This is unlike the SOFC technology relevant condition of high fuel utilization, where the $\mathrm{H}_{2}$ concentration gradient through the anode and support layer at the fuel outlet is small and hence the $\mathrm{H}_{2}$ flux may be insufficient resulting in an apparent fuel starvation. Indications of such unwanted and limiting situations have been observed for cells with a dense metal support layer. Thus, from a performance and technological perspective a more open microstructure is needed. It should be noted that for a more accurate modelling of the microstructural gas transport properties more advanced models such as e.g. the dusty gas model is needed. ${ }^{34}$

Since single cell testing is used for performance evaluation, the fuel utilization is not insignificant as Figures 4, 6 and 7 illustrate. This is unlike button cell testing where the cells are flushed with fuel and

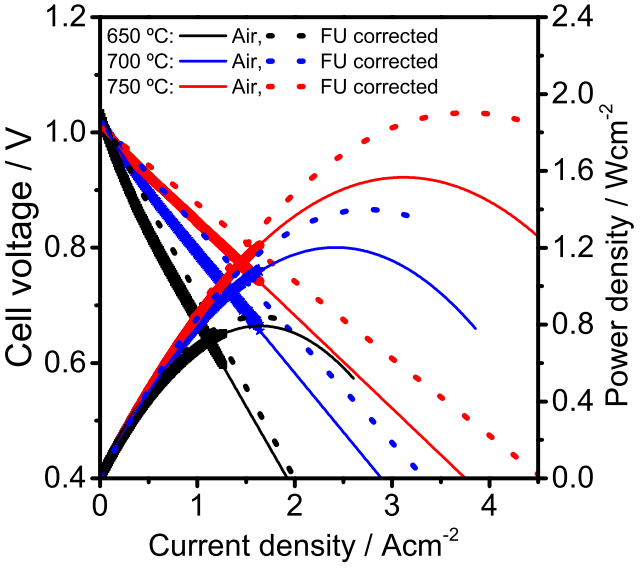

Figure 8. Fuel utilization corrected polarization and power density curves as outlined in Ref. 4.

the effect of fuel utilization is suppressed. This is practical feasible as the active area is very small (typically $\leq 0.5 \mathrm{~cm}^{2}$ ). In addition many variations of button cell setups exist with different gas flow configurations. In the used single cell testing, the flow configuration is similar to what will be present in a stack that is plug flow. Thus, the condition in single cell testing mimics stack conditions and the measured performance of the cell will therefore be very close to what can be expected in a stack environment. The importance and impact of fuel utilization has been considered before in Ref. 19. In here, a methodology for compensating for the fuel utilization has been suggested. An exact compensation of fuel utilization is not feasible, but estimation of a conservative first approximation is feasible. Basically, the methodology attempts to compensate for the change in Nernst potential as the fuel is utilized. Area specific resistances (ASRs) corrected by this methodology is specified as $\mathrm{ASR}_{\text {corr }}$. In Figure 8 the effect of fuel utilization is illustrated on the performance characteristics with air as oxidant of the cell in Figure 7. Assuming linear polarization relationship the calculated $\mathrm{ASR}_{\text {corr }}$ from the measured data has been used to forecast the effect of fuel utilization. As expected it is possible to see that the higher performance at the highest temperature of $750^{\circ} \mathrm{C}$ is affected the most. From the plot it is possible to see a fuel utilization corrected performance of $1.20 \mathrm{Wcm}^{-2}$ at bench marking conditions $@ 0.7 \mathrm{~V}, 700^{\circ} \mathrm{C}$ and a PPD of $1.4 \mathrm{Wcm}^{-2}$ at $700^{\circ} \mathrm{C}$. Key performance characteristics of the studied cells are for convenience summarized in Table III. Thus, MS-SOFCs with higher porosity and therefore improved gas transport properties and higher electrocatalyst loadings does lead to improved performance of the anode and therefore also the cell. Recently, M. Tucker has also shown for a MS-SOFC design with comparable electrode architectures and electrocatalysts that boosting infiltrated electrocatalyst loadings lead to significant performance improvements. ${ }^{4}$ The result was an impressive boosting of the performance at $700^{\circ} \mathrm{C}$ with a peak power density increase from 0.240 $\mathrm{Wcm}^{-2}(0.5 \mathrm{~V})$ to $1.1 \mathrm{Wcm}^{-2}(0.58 \mathrm{~V})$. However, long term testing at an operation at $700^{\circ} \mathrm{C}$ and at $0.7 \mathrm{~V}$ for $1200 \mathrm{~h}$ showed severe degradation with a peak power density loss of $73 \% .{ }^{35}$ A summary of reported key performances in laboratory scale, using different manufacturing process and materials is provided in Table 13 of the recent MS-SOFC review from 2017 by Krishnan. ${ }^{1}$ From the summary it is clear that the performances reported within the present study are superior compared to the reviewed studies in Ref. 1 in particular if temperature is taken into consideration. From the present data it is uncertain how much the anode can be further improved. In any case, there is for even further performance improvements a clear potential for the cathode to be further optimized considering the effect on performance of varying the oxidant gas between air and pure oxygen in both Figures $6 \mathrm{~B}$ and $7 \mathrm{~B}$. At last the electrolyte layer can be further densified and made thinner and thereby additionally boost the performance. 
Table III. Summary of performance characteristics of studied cells. The used abbreviations are as follows FU = fuel utilization, ASR = area specific resistance, $\mathbf{A S R}_{\text {corr }}=$ fuel utilization corrected $\mathbf{A S R}, \mathbf{P P D}=$ peak power density, $\mathbf{P P D}_{\text {corr }}=$ fuel utilization corrected $\mathbf{P P D}$.

\begin{tabular}{|c|c|c|c|}
\hline & DTU SoA MS $313 \mu \mathrm{m}$ & DTU open MS $175 \mu \mathrm{m}$ & DTU open MS $240 \mu \mathrm{m}$ \\
\hline \multicolumn{4}{|c|}{$650^{\circ} \mathrm{C}$} \\
\hline $\operatorname{ASR}(0.6 \mathrm{~V}) / \Omega \mathrm{cm}^{2}$ & 0.48 & 0.38 & 0.34 \\
\hline $\operatorname{ASR}_{\text {corr }}(0.6 \mathrm{~V}) / \Omega \mathrm{cm}^{2}$ & 0.45 & 0.36 & 0.32 \\
\hline $\mathbf{P P D} / \mathrm{Wcm}^{-2}$ & $0.53(0.52 \mathrm{~V}, \mathrm{FU} 34 \%)$ & $0.75(0.47 \mathrm{~V}$, FU $53 \%)$ & $0.80(0.48 \mathrm{~V}, \mathrm{FU} 55 \%)$ \\
\hline $\mathbf{P P D}_{\text {corr }} / \mathbf{W c m}^{-2}$ & $0.60(0.52 \mathrm{~V})$ & $0.76(0.52 \mathrm{~V})$ & $0.84(0.51 \mathrm{~V})$ \\
\hline \multicolumn{4}{|c|}{$700^{\circ} \mathrm{C}$} \\
\hline $\operatorname{ASR}(0.6 \mathrm{~V}) / \Omega \mathrm{cm}^{2}$ & 0.32 & 0.25 & 0.22 \\
\hline $\operatorname{ASR}_{\text {corr }}(0.6 \mathrm{~V}) / \Omega \mathrm{cm}^{2}$ & 0.29 & 0.22 & 0.19 \\
\hline $\mathbf{P P D} / \mathrm{Wcm}^{-2}$ & $0.78(0.52$ V, FU 50\%) & $1.12(0.48 \mathrm{~V}, \mathrm{FU} 78 \%)$ & $1.20(0.50 \mathrm{~V}, \mathrm{FU} 81 \%)$ \\
\hline $\mathbf{P P D}_{\text {corr }} / \mathrm{Wcm}^{-2}$ & $0.90(0.51 \mathrm{~V})$ & $1.22(0.52 \mathrm{~V})$ & $1.40(0.51 \mathrm{~V})$ \\
\hline \multicolumn{4}{|c|}{$750^{\circ} \mathrm{C}$} \\
\hline $\operatorname{ASR}(0.6 \mathrm{~V}) / \Omega \mathrm{cm}^{2}$ & - & 0.18 & 0.17 \\
\hline $\mathrm{ASR}_{\text {corr }}(0.6 \mathrm{~V}) / \Omega \mathrm{cm}^{2}$ & - & 0.15 & 0.13 \\
\hline $\mathbf{P P D} / \mathrm{Wcm}^{-2}$ & - & $1.40(0.50 \mathrm{~V}, \mathrm{FU} 92 \%)$ & $1.56(0.62 \mathrm{~V}, \mathrm{FU} 100 \%)$ \\
\hline $\mathbf{P P D}_{\text {corr }} / \mathrm{Wcm}^{-2}$ & - & $1.69(0.51 \mathrm{~V})$ & $1.90(0.50 \mathrm{~V})$ \\
\hline \multicolumn{4}{|c|}{ Benchmarking @ $0.7 \mathrm{~V}, 700^{\circ} \mathrm{C}$} \\
\hline Benchmarking / $\mathrm{Wcm}^{-2}$ & 0.69 (FU 33\%) & 0.89 (FU 43\%) & $1.01(\mathrm{FU} 48 \%)$ \\
\hline Benchmarking corr / $\mathrm{Wcm}^{-2}$ & 0.79 & 1.06 & 1.22 \\
\hline
\end{tabular}

\section{Conclusions}

It was demonstrated possible in the DTU MS-SOFC design and fabrication route to reduce the metal support considerable from standard $313 \mu \mathrm{m}$ to $108 \mu \mathrm{m}$. However, upon the reduction of the metal support layer thickness an increased densification of the layer and an associated performance loss was observed. To mitigate the performance loss, two routes for increasing the porosity of the support layer was demonstrated possible. The first route was introduction of gas channels via puncturing of the green tape casted support layer. In the case of an average gas channel spacing of $235 \mu \mathrm{m}$ on MSSOFCs with a support thickness of $175 \mu \mathrm{m}$ a significant performance improvement was observed. The second route was a 5 fold reduction of the sintering temperature dwell time, which lead to significant increase of the support porosity. This resulted in signicant performance improvements with a maximum increase of $46 \%$ in performance to $1.01 \mathrm{Wcm}^{-2}$ at $0.7 \mathrm{~V}, 700^{\circ} \mathrm{C}$ with a $\mathrm{FU}$ of $48 \%$. This corresponds to fuel utilization corrected peak power densities of $0.84 \mathrm{Wcm}^{-2}$ at $650^{\circ} \mathrm{C}, 1.40 \mathrm{Wcm}^{-2}$ at $700^{\circ} \mathrm{C}$ and $1.90 \mathrm{Wcm}^{-2}$ at $750^{\circ} \mathrm{C}$. All results were obtained on gastight stack technology relevant sized cells of 12 $\mathrm{cm} \times 12 \mathrm{~cm}$.

\section{Acknowledgment}

Financial support by NISSAN MOTOR CO., LTD. is gratefully acknowledged.

\section{References}

1. V. V. Krishnan, WIREs Energy Environ, 6 (5), 246 (2017)

2. A. M. Dayaghi, K. J. Kim, S. Kim, J. Park, S. J. Kim, B. H. Park, and G. M. Choi, Journal of Power Sources, 324, 288 (2016).

3. Y. Zhou, X. Menga, X. Liu, X. Pan, J. Lia, X. Ye, H. Nie, C. Xia, S. Wang, and Z. Zhan, Journal of Power Sources, 267, 148 (2014).

4. M. C. Tucker, Energy Technol., 5, 2175 (2017).

5. S. (Rob) Hui, D. Yang, Z. Wang, S. Yick, C. Petit, W. Qu, A. Tuck, R. Maric, and D. Ghosh, Journal of Power Sources, 167, 336 (2007).

6. Z. Liu, B. Liu, D. Ding, Z. Jiang, and C. Xia, International Journal of Hydrogen Energy, 37, 4401 (2012)

7. R. Hui, J. O. Berghaus, C. Decès-Petit, W. Qu, S. Yick, J.-G. Legoux, and C. Moreau, Journal of Power Sources, 191, 371 (2009).

8. S.-W. Baek, J. Jeong, H. Schlegl, A. K. Azad, D. S. Park, U. B. Baek, and J. H. Kim, Ceramics International, 42, 2402 (2016).
9. E. Hermawan, G. S. Lee, G. S. Kim, H. C. Ham, J. Han, and S. P. Yoon, Ceramics International, 43, 10450 (2017).

10. I. Villarreal, C. Jacobson, A. Leming, Y. Matus, S. Visco, and L. De Jonghe, Electrochemical and Solid-State Letters, 6(9), A178 (2003).

11. E. Mercadelli, A. Gondolini, P. Pinasco, and A. Sanson, Met. Mater. Int., 23 (1), 184, (2017).

12. A. Ansar, P. Szabo, J. Arnold, Z. Ilhan, D. Soysal, R. Costa, A. Zagst, M. Gindrat, and T. Franco, ECS Transactions, 35 (1), 147 (2011).

13. D. Roehrens, F. Han, M. Haydn, W. Schafbauer, D. Sebold, N. H. Menzler, and H. P. Buchkremer, International Journal of Hydrogen Energy, 40, 11538 (2015).

14. R. T. Leah, N. P. Brandon, and P. Aguiar, Journal of Power Sources, 145, 336 (2005).

15. R. Leah, A. Bone, M. Lankin, A. Selcuk, M. Rahman, A. Clare, L. Rees, S. Phillip, S. Mukerjee, and M. Selby, ECS Transactions, 68 (1) 95 (2015).

16. T. Klemensø, J. Nielsen, P. Blennow, A., H. Persson, T. Stegk, B. H. Christensen, and S. Sønderby, J. Power Sources, 196, 9459 (2011).

17. P. Blennow, J. Hjelm, T. Klemens $\varnothing$, S. Ramousse, A. Kromp, A. Leonide, and A. Weber, J. Power Sources, 196, 7117 (2011).

18. P. Blennow, J. Hjelm, T. Klemens $\emptyset$, Å., H. Persson, S. Ramousse, and M. Mogensen, Fuel Cells, 11, 661 (2011).

19. M. Mogensen and P. V Hendriksen, in High Temperature Solid Oxide Fuel Cells: Fundamentals, Design, and Applications, S. C. Singhal and K. Kendall, Editors, p. 261, Elsevier Advanced Technology, Oxford (2003).

20. S. H. Jensen, J. Hjelm, A. Hagen, and M. Mogensen, in Handbook of fuel cells: Advances in Electrocatalysis, Materials, Diagnostics and Durability, W. Vielstich, H. Yokokawa, and H.A. Gasteiger, Editors, Vol. 5-6, chapter 53, John Wiley \& Sons, (2009).

21. H. Schichlein, A. C. Müller, M. Voights, A. Krügel, and E. Ivers-Tiffeé, Journal of Applied Electrochemistry, 32, 875, (2002).

22. G. Reiss, H. L. Frandsen, W. Brandstätter, and A. Weber, J. Power Sources, 273, 1006 (2015).

23. H. Iwaia, N. Shikazonob, T. Matsuic, H. Teshimab, M. Kishimotoa, R. Kishidac, D. Hayashia, K. Matsuzakib, D. Kannob, M. Saitoa, H. Muroyamac, K. Eguchic, and N. Kasagib, J. Power Sources, 195, 955 (2010).

24. S. Gewiesz and W. G. Bessler, J. Electrochem. Soc, 155, B937 (2008).

25. A. E. Richards, M. G. McNeeley, R. J. Kee, and N. P. Sullivan, J. Power Sources, 196, 10010 (2011)

26. N. Epstein, Chem. Eng. Sci., 44, 777 (1989).

27. S. Jung, C. Lu, H. He, K. Ahn, R. J. Gorte, and J. M. Vohs, Journal of Power Sources, 154, 42 (2006).

28. J. Nielsen, T. Klemens $\varnothing$, and P. Blennow, J. Power Sources, 219, 305 (2012).

29. J. Nielsen and J. Hjelm, Electrochimica Acta, 115, 31 (2014).

30. J. Nielsen, B. R. Sudireddy, A. Hagen, and A. H. Persson, J. Electrochem. Soc., 163 F574 (2016).

31. S. Primdahl and M. Mogensen, J. Electrochem. Soc., 145, 2431 (1998).

32. W. G. Bessler, Journal of The Electrochemical Society, 153, A1492 (2006).

33. T. Jacobsen, P. V. Hendriksen, and S. Koch, Electrochimica Acta., 53, 7500 (2008).

34. A. Bertei and C. Nicolella, Journal of Power Sources, 279, 133 (2015).

35. M. C. Tucker, Journal of Power Sources, 369, 6 (2017). 